\title{
Assessing the effects of ambient ozone in China on snap bean genotypes by using ethylenediurea (EDU)
}

\author{
Xiangyang Yuan ${ }^{\mathrm{a}, \mathrm{c}}$, Vicent Calatayud ${ }^{\mathrm{a}, \mathrm{b}}$, Lijun Jiang ${ }^{\mathrm{a}}$, William J. Manning ${ }^{\mathrm{d}}$, \\ Felicity Hayes ${ }^{\mathrm{e}}$, Yuan Tian ${ }^{\mathrm{c}}$, Zhaozhong Feng ${ }^{\mathrm{a},{ }^{*}}$ \\ ${ }^{a}$ Research Center for Eco-Environmental Sciences, Chinese Academy of Sciences, Shuangqing Road 18, Haidian District, Beijing 100085, China \\ ${ }^{\mathrm{b}}$ Fundación CEAM, c/Charles R. Darwin 14, Parque Tecnológico, 46980 Paterna, Valencia, Spain \\ ${ }^{c}$ Department of Food, Beijing Technology and Business University, Fucheng Road 11, Haidian District, Beijing 100048, China \\ d Stockbridge School of Agriculture, University of Massachusetts, Amherst, MA 01003-9320, USA \\ e Centre for Ecology and Hydrology, Environment Centre Wales, Deiniol Road, Bangor, Gwynedd LL57 2UW, UK
}

\section{A R T I C L E I N F O}

\section{Article history:}

Received 21 February 2015

Received in revised form 23 May 2015

Accepted 26 May 2015

Available online 12 June 2015

\section{Keywords:}

Ambient ozone

Ethylenediurea

Photosynthesis

Snap bean

Yield

\begin{abstract}
A B S T R A C T
Four genotypes of snap bean (Phaseolus vulgaris L.) were selected to study the effects of ambient ozone concentration at a cropland area around Beijing by using $450 \mathrm{ppm}$ of ethylenediurea (EDU) as a chemical protectant. During the growing season, the $8 \mathrm{~h}$ (9:00-17:00) average ozone concentration was very high, approximately $71.3 \mathrm{ppb}$, and AOT40 was $29.0 \mathrm{ppm}$.h. All genotypes showed foliar injury, but ozonesensitive genotypes exhibited much more injury than ozone-tolerant ones. Compared with control, EDU significantly alleviated foliar injury, increased photosynthesis rate and chlorophyll $a$ fluorescence, $V c_{\max }$ and $\mathrm{J}_{\max }$, and seed and pod weights in ozone-sensitive genotypes but not in ozone-tolerant genotypes. EDU did not significantly affect antioxidant contents in any of the genotypes. Therefore, EDU effectively protected sensitive genotypes from ambient ozone damage, while protection on ozonetolerant genotypes was limited. EDU can be regarded as a useful tool in risk assessment of ambient ozone on food security.
\end{abstract}

๑) 2015 Elsevier Ltd. All rights reserved.

\section{Introduction}

As the industrialization and urbanization processes accelerate, tropospheric ozone is increasing worldwide at a range of $0.5-2 \%$ per year during the 21st century (IPCC, 2013; Vingarzan, 2004). Ground-level ozone pollution is affecting human health and food security in both developing and developed countries (Dentener et al., 2005; Fiscus et al., 2005). In China, massive fossil fuel consumption in the last three decades has produced a lot of nitrogen oxides and volatile organic compounds, and thus ozone concentrations have increased significantly (Feng et al., 2015; Wang et al., 2006). In most parts of China, mean daily 8 h (9:00-17:00) ozone concentration over 50-60 ppb have been documented (Feng et al., 2015; Jiang et al., 2012; Wang and Mauzerall, 2004).

High ozone concentration induced negative effects on Chinese plants and crops. Feng et al. (2014) reported that leaf ozone injury was widespread in the Beijing area, with 28 different species

\footnotetext{
* Corresponding author.

E-mail address: fzz@rcees.ac.cn (Z. Feng).
}

(including trees, shrubs, and crops) showing typical ozone symptoms. Results from Open Top Chamber experiments in Northeast China suggest that mean ozone concentrations of $58.6 \mathrm{ppb}$ significantly reduce yield by $40 \%$ (with a range of $32-46 \%$ ) in eight soybean genotypes (Zhang et al., 2014). A modeling study suggested that ozone reduced yield of four important crops (wheat, rice, maize and soybean) in China by $1-23 \%$ in the 1990 s, and predicted further reductions (between 7 and 64\%) for 2020 (Van Dingenen et al., 2009; Wang and Mauzerall, 2004).

Ethylenediurea (N-[2-(2-oxo-1-imidazolidinyl)ethyl]-N-phenyl urea), abbreviated as EDU, has been used extensively to assess the ozone-induced impacts on many crops, e.g wheat, potato, bean, and tomato (Feng et al., 2010a). The application of EDU as a 'control' to ambient ozone is useful to determine ambient ozone effects in fieldgrown plants, particularly in many remote and developing regions where electricity and funding are limited (Blum et al., 1998; Hassan et al., 1995; Manning et al., 2011; Tiwari and Agrawal, 2010). EDU is regarded to act in the apoplast as a potential chemical scavenger (Gatta et al., 1997), thus protecting plants from ozone injury by increasing the antioxidant capacity of the leaf (Pandey et al., 2014; 
Singh et al., 2009; Tiwari and Agrawal, 2010).

In China, several studies have investigated the effects of elevated ozone (higher than ambient ozone concentration) on crops, e.g. wheat, rice, in Open-Top Chambers and in Free Air Ozone Enrichment Systems (Feng et al., 2015). So far, only one study has focused on the effects of ambient ozone levels on individual cultivars of wheat and rice (Wang et al., 2007). However, it is crucial to quantify the effects of ambient ozone on crops and thus risk assessment of ozone on food security. Snap bean (Phaseolus vulgaris L.) has been previously used in biomonitoring studies in different parts of the world (Burkey et al., 2005, 2012; Elagoz and Manning, 2005; Fiscus et al., 2012; Flowers et al., 2007; Harmens et al., 2009), but not applied in China, where ozone levels are particularly high. Different snap bean genotypes show a contrasting sensitivity to ozone (Burkey et al., 2005; Elagoz and Manning, 2005; Flowers et al., 2007).

In the present study, four bean genotypes, 'S156' (ozone-sensitive) and 'R123' (ozone-tolerant), and two Chinese genotypes, 'DDW' and 'NX816' were exposed to ambient ozone in Beijing, China. The objectives of this study are to use EDU as a tool for assessing the impacts of current ambient ozone levels on a common crop in Beijing, including the use of commonly planted bean genotypes and to clarify the physiological mechanisms related with the contrasting ozone sensitivity of different bean genotypes.

\section{Materials and methods}

\subsection{Experimental site}

This study was conducted under ambient conditions at Changping cropland area $\left(40^{\circ} 19^{\prime} \mathrm{N}, 116^{\circ} 13^{\prime} \mathrm{E}\right)$. The climate type is continental monsoon. Meteorological data at the experimental site during the study period, from June 4 to September 10, are provided in Table 1.

\subsection{Plant material and experimental design}

For the present study, four genotypes of snap bean were selected. Seeds of genotype 'S156' (ozone-sensitive) and 'R123' (ozone-tolerant), as used in the ICP Vegetation biomonitoring programme (e.g. Harmens et al., 2009), were provided by Raleigh USDA-ARS (United States Department of Agriculture, Agricultural Research Institute of Plant Science Research Center). Two Chinese genotypes 'DDW' and 'NX816' were also selected as they are commonly planted by farmers in North China Plain and DDW showed leaf visible ozone injury in the field in 2013. The life span of all genotypes is similar, approximately 110 days under local growth condition.

Plants were grown in $20 \mathrm{~L}$ pots filled with compost under ambient field conditions from May 25 to September 10, 2014. Two seeds per pot were planted but only one plant per pot was kept when the true leaves emerged. Pots were regularly irrigated in order to keep moisture uniform, close to field capacity.

Table 1

Monthly average of temperature (T) and their daily maximum and minimum averaged $\mathrm{T}$ values, accumulated precipitation $(\mathrm{P})$ and sunshine hours at Changping (Beijing) from June 4 to September 10, 2014.

\begin{tabular}{lcccc}
\hline Month & June & July & August & September \\
\hline Average T $\left({ }^{\circ} \mathrm{C}\right)$ & 24.2 & 27.4 & 25.3 & 20.6 \\
Avg. max $\left({ }^{\circ} \mathrm{C}\right)$ & 37.5 & 37.5 & 35.8 & 34.6 \\
Avg. min T $\left({ }^{\circ} \mathrm{C}\right)$ & 12.5 & 18.7 & 14.5 & 8.7 \\
Total P $(\mathrm{mm})$ & 51 & 130 & 93 & 34 \\
Sunshine hours $(\mathrm{h})$ & 238.2 & 202.7 & 209.3 & 215.3 \\
\hline
\end{tabular}

\subsection{EDU application}

The results of Feng et al. (2010a) and Manning et al. (2011) showed that $450 \mathrm{ppm}$ EDU effectively protect different plants species from ozone. Therefore, half of the plants were treated with $450 \mathrm{ppm}$ EDU (E+ from now on) and half with water (E- from now on) in current study. EDU solution was freshly prepared each time, dissolving $100 \%$ EDU wettable powder in lukewarm water. Treatments started at 10 days after planting (DAP), when the first trifoliate leaf emerged, and then applied as a foliar spray at regular biweekly intervals until final harvest.

\subsection{Ozone concentrations}

Ozone concentrations were measured hourly using an ozone analyzer (Model 49i, Thermo, USA) during the growing season. Mean hourly ozone concentrations and AOT40 (hourly Accumulated Ozone exposure over a Threshold of $40 \mathrm{ppb}$, from 8:00 to 17:00) were calculated. Notably, the site is far from cities, in a typical rural environment, not close to any $\mathrm{NOx}$ and $\mathrm{SO}_{2}$ emission source. Therefore, it is not expected that these two pollutants are very relevant for the experiment.

\subsection{Assessment of ozone visible injury}

All plants were examined weekly in order to record foliar visible injury. For each plant, all trifoliate leaves (excluding primary leaves and any cotyledons still present) were scored for ozone visible injury in 5 classes: 1) $0-5 \%, 2) 5-25 \%, 3) 25 \%-50 \%$, 4) $50 \%-75 \%$, and 5 ) $>75 \%$. A Leaf Injury Index (LII) per plant was calculated according to Furlan et al. (2007).

\subsection{Photosynthetic parameters}

Gas exchange and chlorophyll $a$ fluorescence parameters were measured using a portable photosynthetic system (LI-6400XT, LICOR Corp., USA) at different growth stages (28 DAP, 40 DAP, and 63 DAP) in all plants. Measurements were carried out between 9:00-11:00 $\mathrm{h}$ in sunny days on fully-expanded leaves from the top of the plants. During the measurements, photosynthetic active radiation (PAR) was set at $1200 \mu \mathrm{mol} \mathrm{m} \mathrm{m}^{-2} \mathrm{~s}^{-1}, \mathrm{CO}_{2}$ levels at $400 \mathrm{ppm}$, leaf $\mathrm{T}$ at $30{ }^{\circ} \mathrm{C}$, and $\mathrm{RH}$ between $50 \%$ and $70 \%$. The following parameters were determined: light-saturated rate of $\mathrm{CO}_{2}$ assimilation $\left(A_{\text {sat }}\right)$, stomatal conductance $\left(g_{\mathrm{s}}\right)$, actual photochemical efficiency of PSII in the saturated light $\left(F_{\mathrm{v}}^{\prime} / F_{\mathrm{m}}^{\prime}\right)$, quenching of photochemical efficiency of PSII $(q \mathrm{P})$, and electron transport rate (ETR).

In addition, at $30 \mathrm{DAP}, 42 \mathrm{DAP}$ and $64 \mathrm{DAP}, A / C i$ curves were performed using the automatic program of the LI-6400XT at a PAR of $1200 \mu \mathrm{mol} \mathrm{m} \mathrm{m}^{-2} \mathrm{~s}^{-1}$ and the same T and RH conditions with $A_{\text {sat }}$ measurements. The maximum rates of Rubisco carboxylation $\left(V c_{\max }\right)$ and the maximum electron transport rates $\left(J_{\max }\right)$ were subsequently calculated according to the methods described by Sharkey et al. (2007).

\subsection{Pigment, antioxidant and MDA contents}

Leaf samples for pigment, antioxidant and malondialdehyde (MDA) contents were collected on sunny days at 40 DAP from fullyexpanded leaves on the top of the plants, similar to those for photosynthetic measurements. Samples from two leaves per plant from each genotype and EDU treatment were taken, frozen immediately in liquid nitrogen, and stored at $-80^{\circ} \mathrm{C}$ until analysis.

Chlorophyll and carotenoid contents were analyzed using the methods described by Lichtenthaler (1989). MDA content, which is related with the level of lipid peroxidation in the leaves, was 
analyzed according the method of Heath and Parker (1968), based on the thiobarbituric acid (TBA) reaction. For Ascorbic acid determination, two leaf discs per plant $(\sim 30 \mathrm{mg})$ were homogenized in a pre-chilled mortar and extracted in $2 \mathrm{ml}$ ice-cold $6 \%(\mathrm{w} / \mathrm{v})$ trichloroacetic acid, and then centrifugated at $13,000 \mathrm{~g}$ for $5 \mathrm{~min}$ at $4{ }^{\circ} \mathrm{C}$. Ascorbic acid was estimated following Gillespie and Ainsworth (2007). Total phenolic content was determined by the method of Ainsworth and Gillespie (2007), using Folin-ciocalteu reagent and $\mathrm{Na}_{2} \mathrm{CO}_{3}$. For total antioxidant capacity (TAC) determinations, $2 \mathrm{ml}$ cold $70 \%(\mathrm{v} / \mathrm{v})$ ethanol was added to leaf disc samples $(\sim 30 \mathrm{mg})$ and homogenized in darkness. The mixture was centrifuged at $13,000 \mathrm{~g}$ for $10 \mathrm{~min}$, and $0.1 \mathrm{ml}$ supernatant was taken for the ferric reducing antioxidant power (FRAP) assay according to Benzie and Strain (1996).

\subsection{Yield and biomass}

All plants were harvested at 108 DAP when at least $50 \%$ of the pods of each plant had reached the fully mature brown stage. Pods $<2 \mathrm{~cm}$ were neither harvested nor counted. Pods were subsequently air-dried to constant weight. Shoot and root dry biomass were also determined after drying the different parts of the plants at $80^{\circ} \mathrm{C}$ until constant weight.

\subsection{Statistical analyses}

The data for each dependent variable was subjected to the analysis of variance with mixed linear model to test the effects of EDU, genotypes and their interactions using JMP software (SAS Institute, USA). Tukey's HSD test was applied to identify significant differences between EDU treatments or among genotypes. A difference between the means was considered significant if $P \leq 0.05$. Data shown in Figures were means \pm SD $(n=5)$.

\section{Results}

\subsection{Ozone concentrations}

Ambient ozone concentrations and AOT40 during daytime hours (9:00-17:00) along the study period (June 4 to September 10) were shown in Fig. 1. For the 108 days of the experiment, $8 \mathrm{~h}$ (9:00-17:00) average ozone concentration was 71.3 ppb. Considering hourly means, more than $90 \%$ of the hours were above $40 \mathrm{ppb}$, while $23 \%, 32 \%, 26 \%, 22 \%$ of them exceeded $100 \mathrm{ppb}$ in June, July, August and September, respectively (Table 2). Peak 1-h values for

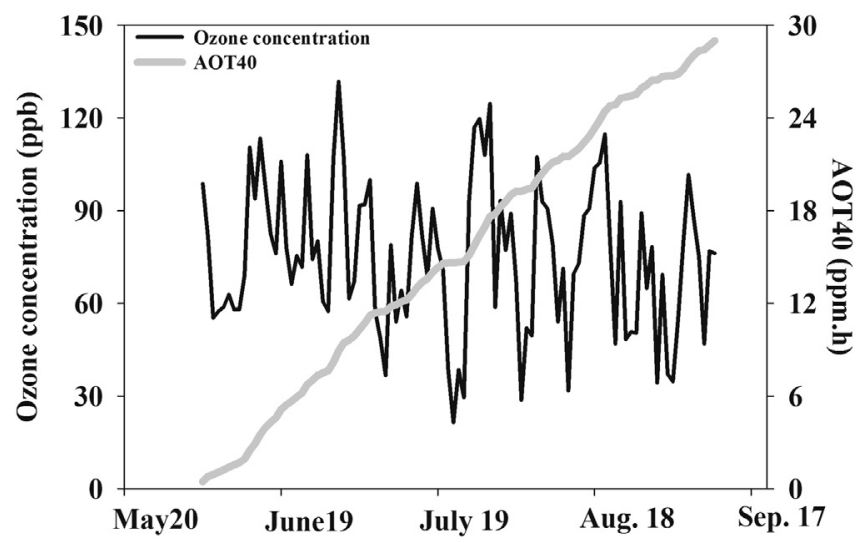

Fig. 1. Variations in $8 \mathrm{~h}$ (9:00-17:00) mean ozone concentrations and AOT40 during the study period from June 4 to September 10 .
Table 2

Distribution of hourly ozone concentrations during daily hours (9:00-17:00) in different ozone intervals from June 4 to September 10 at the experimental site (Beijing, China).

\begin{tabular}{lccll}
\hline Concentration (ppb) & \multicolumn{3}{l}{ Number of hours } \\
\cline { 2 - 5 } & \multicolumn{2}{l}{2014} & & \\
\cline { 2 - 5 } & June & July & August & September \\
\hline$>30-\leq 40$ & 2 & 12 & 19 & 13 \\
$>40-\leq 50$ & 16 & 24 & 28 & 11 \\
$>50-\leq 60$ & 38 & 39 & 38 & 10 \\
$>60-\leq 70$ & 28 & 22 & 28 & 5 \\
$>70-\leq 80$ & 31 & 19 & 22 & 9 \\
$>80-\leq 90$ & 32 & 15 & 19 & 5 \\
$>90-\leq 100$ & 17 & 16 & 17 & 5 \\
$>100-\leq 110$ & 12 & 23 & 25 & 8 \\
$>110-\leq 120$ & 19 & 13 & 15 & 5 \\
$>120-\leq 130$ & 6 & 10 & 8 & 2 \\
$>130-\leq 140$ & 7 & 8 & 8 & 1 \\
$>140-\leq 150$ & 3 & 9 & 3 & \\
$>150-\leq 160$ & 2 & 4 & & \\
$>160-\leq 170$ & 1 & 3 & & \\
\hline
\end{tabular}

June, July, August and September were 173.6, 170.4, 144.6 and $135.3 \mathrm{ppb}$, respectively. At the end of the experiment, AOT40 reached 29.04 ppm.h.

\subsection{Ozone visible injury}

Ambient ozone concentrations induced visible symptoms in all genotypes during growth. Visible injury was observed first in Eplants of S156 at 23 DAP before the flowering day. In the other genotypes, symptom onset was observed after the flowering day, at 37 DAP, 44 DAP and 79 DAP in R123, DDW and NX816, respectively. Treatment with EDU delayed the onset of visible injury 10 days in S156, 7 days in both R123 and DDW, but had no effect on symptom onset in NX816 (Fig. 2).

In the non-EDU treatment, two genotypes (S156 and DDW) consistently exhibited more symptoms ( $>40 \%$ ) than the other two genotypes $(<20 \%)$ (Fig. 2). The results suggested that S156 and DDW are ozone-sensitive genotypes, but R123 and NX816 are ozone-tolerent ones. The observed decline in Leaf Injury Index in S156 at 79 DAP can be interpreted by abscission of older leaves with higher injury scores. EDU clearly protected these two sensitive genotypes from visible injury as visible injury at the end was about half that of the E-treatment. On the other hand, EDU had no significant effect on the two tolerant genotypes, as both $\mathrm{E}+$ and $\mathrm{E}-$ treatments showed similar LII at the end of the experiment.

Complementary microscopy analyses of leaf sections showed cell collapse in the palisade parenchyma of E-sensitive genotypes while parenchyma was not altered in tolerant genotypes and in $\mathrm{E}+$ treated plants (Fig. S1).

\subsection{Photosynthesis and pigments}

At 40 DAP, EDU significantly increased chlorophyll and carotenoid contents in S156 but not in the other genotypes (Fig. 3), while $\mathrm{Chl}$ a/b ratio significantly increased in both S156 and DDW.

At the beginning of the experiment (28 DAP), $A_{\text {sat }}$ was not significantly different between genotypes or EDU treatments (Fig. 4). As plants were exposed to ambient ozone levels for longer periods, differences between genotypes and EDU treatments became evident. EDU significantly increased $A_{\text {sat }}$ of S156 (54\% and $78 \%$, at 40 and 63 DAP, respectively) and DDW (57\% and $47 \%$, at 40 and 63 DAP, respectively). No significant effects were, however, observed in the two tolerant genotypes. A similar pattern of 


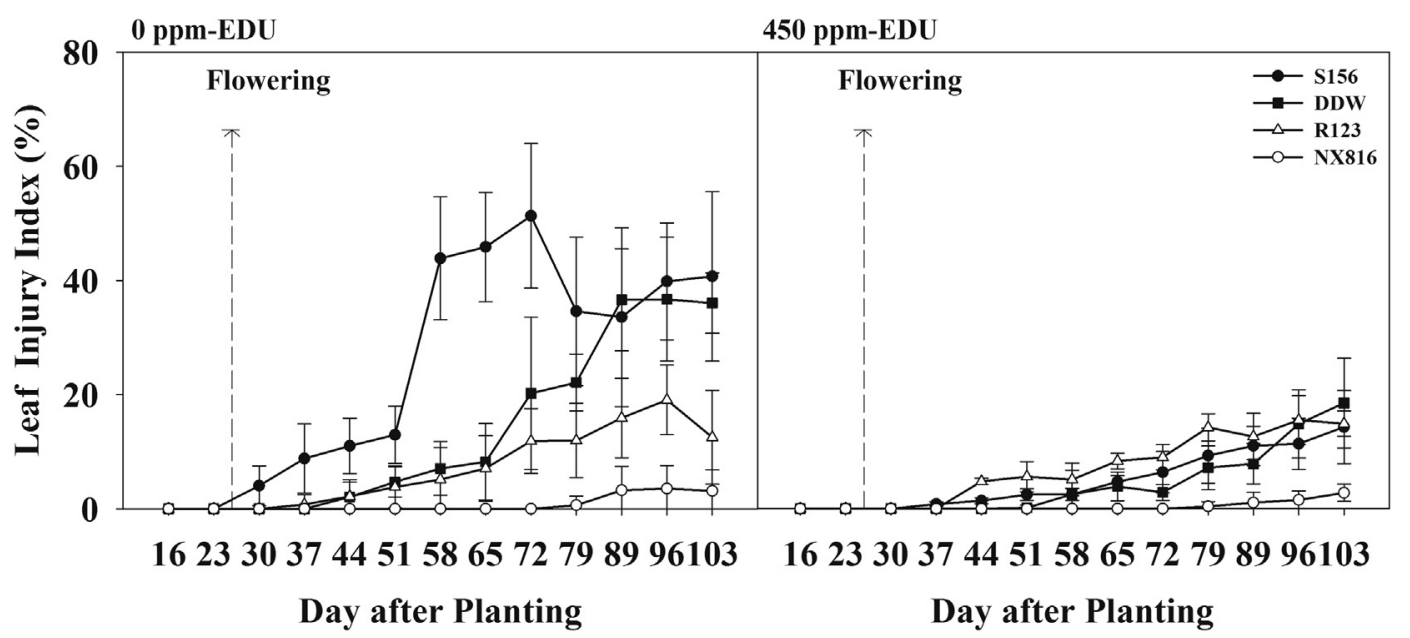

Fig. 2. Leaf injury index in non-EDU and EDU treated plants during the study period.

response was observed for $g_{s}$ at 40 and 63 DAP, although at 40 DAP there was a transitory $g_{s}$ decrease in E+ R123.

EDU affected chlorophyll $a$ fluorescence parameters $\left(F_{\mathrm{v}}^{\prime} / F_{\mathrm{m}}^{\prime}\right.$, ETR, and $q \mathrm{P})$ under steady light conditions in a different way for the four genotypes. All significant changes were observed only in the two sensitive genotypes: At $40 \mathrm{DAP}, F_{\mathrm{v}}^{\prime} / F_{\mathrm{m}}^{\prime}$ and ETR were significantly higher in $\mathrm{E}+\mathrm{S} 156$, and ETR and $q \mathrm{P}$ in $\mathrm{E}+\mathrm{DDW}$. At $63 \mathrm{DAP}, F_{\mathrm{v}}^{\prime} / F_{\mathrm{m}}^{\prime}$, ETR and $q \mathrm{P}$ were significantly higher in $\mathrm{E}+$ plants of S156, and $F_{\mathrm{v}}^{\prime} / F_{\mathrm{m}}^{\prime}$, ETR in DDW (Figs. 5 and 6 ).

Changes in $V c_{\max }$ and $J_{\max }$ were also consistent with observed changes in $A_{\text {sat }}$, and differed between genotypes. At $42 \mathrm{DAP}, V c_{\max }$ and $J_{\max }$ significantly increased in $\mathrm{E}+$ plants in the $\mathrm{S} 156\left(V c_{\max }\right.$ by $27 \%$ and $J_{\max }$ by $40 \%$ ), and $V c_{\max }$ increased by $26 \%$ in DDW (Fig. 7 ). No significant effects were observed in the two ozone-resistant genotypes. At 63 DAP, all genotypes showed a decrease in both parameters with regard to $30 \mathrm{DAP}$, consistent with a late stage in which leaf senescence increases. The observed differences at 42 DAP in $V c_{\max }$ and $J_{\max }$ values between $\mathrm{E}+$ and $\mathrm{E}$ - plants in the two sensitive genotypes increased further at 63 DAP: $V c_{\max }$ of E+ S156 plants increased by $60 \%$ and $J_{\max }$ by $53 \%$, while in DDW, $V c_{\max }$ increased by $41 \%$. As at 42 DAP, the EDU treatment neither induced any significant change in $V c_{\max }$ or $J_{\max }$ in the two tolerant genotypes at 63 DAP.

\subsection{Antioxidant and MDA contents}

The different genotypes showed significant differences in ascorbate (AsA) and phenolic contents, as well as in TAC. The

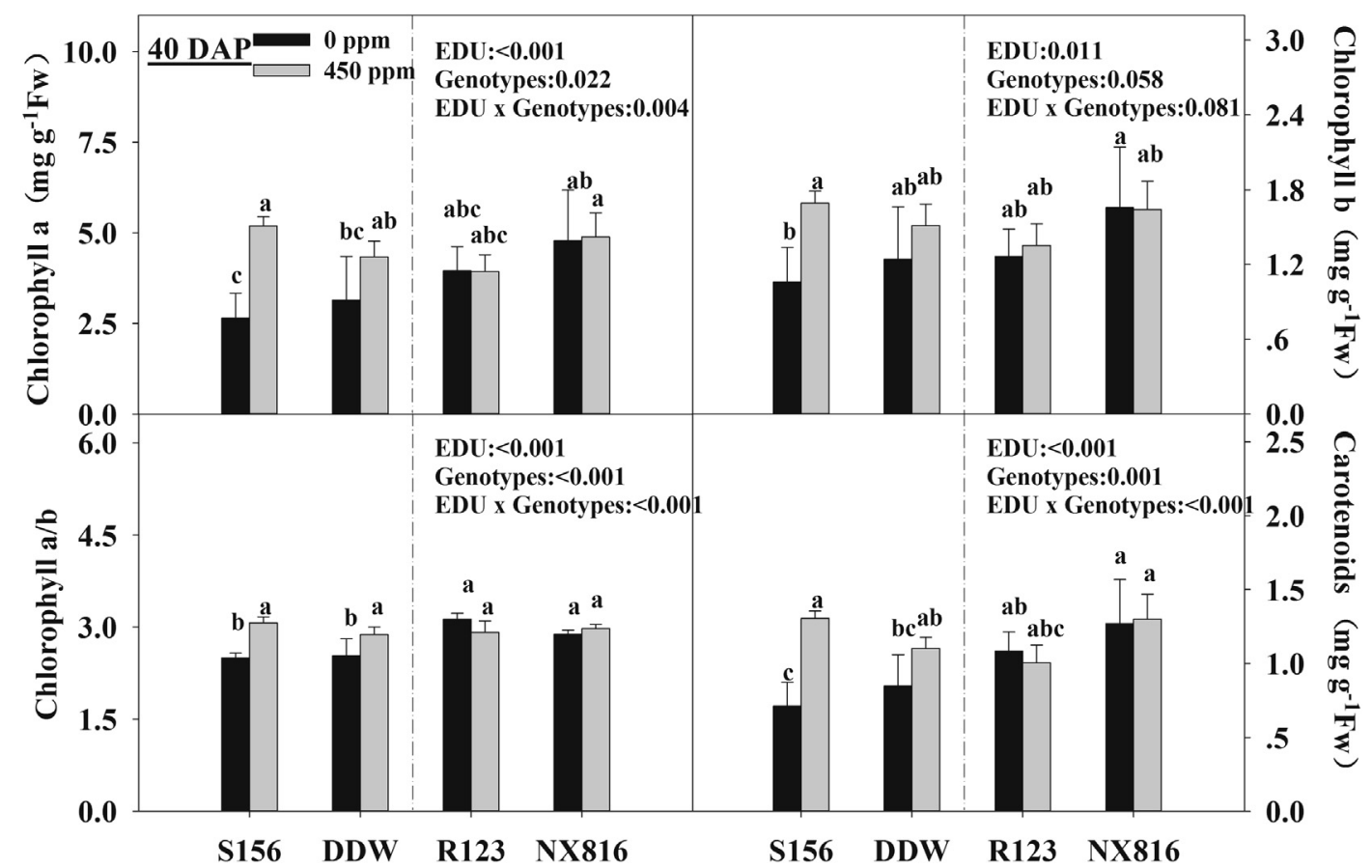

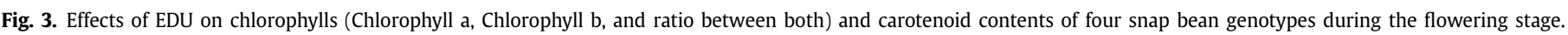
Different letters indicate significant differences between EDU $\times$ genotypes. 


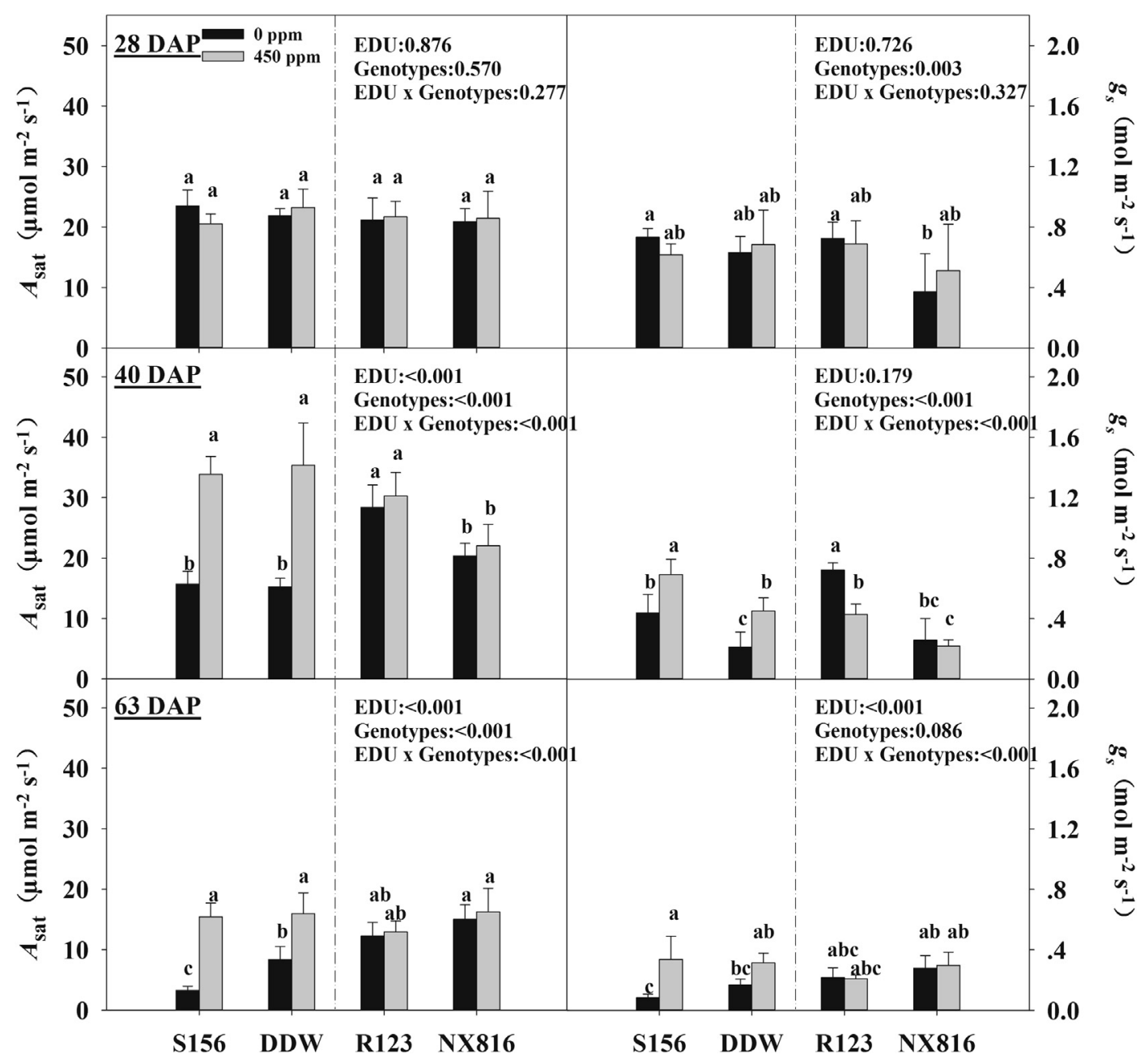

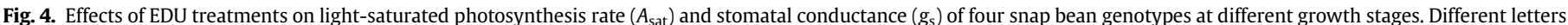
indicate significant differences between EDU $\times$ genotypes.

highest mean of AsA and TAC values were found in NX816 (Fig. 8). Differences in MDA contents among genotypes were not consistently correlated with the classification of the genotypes as sensitive or tolerant. When all the genotypes were considered together, a consistent increase in TAC was observed in $\mathrm{E}+$ plants $(P=0.057)$. There was a significant interaction between EDU and genotypes, with much lower MDA values in $\mathrm{E}+$ plants of the two sensitive genotypes, and practically identical mean values or an increase in the two tolerant genotypes (Fig. 8).

\subsection{Biomass and yield parameters}

EDU treatment produced a significant increase in shoot and root dry weight when all the genotypes are considered together (Fig. 9). EDU effects on yield differed significantly between genotypes. EDU significantly increased the pod weight per plant by $55 \%$ and $46 \%$ in S156 and DDW, respectively, and seed weight in S156 by $56 \%$. Changes in the ozone-tolerant genotypes were not significant.

\section{Discussion}

During year 2014, very high ambient ozone concentrations were measured at the experimental site, northwest of Beijing. Between June 4 and September 10, the $8 \mathrm{~h}$ (9:00-17:00) average ozone concentration was $71.3 \mathrm{ppb}$, with $90 \%$ of the hourly concentrations exceeding $40 \mathrm{ppb}$ (most of them ranging between 40 and $100 \mathrm{ppb}$ ), and peak concentrations above $170 \mathrm{ppb}$. AOT40 was $29.04 \mathrm{ppm} . \mathrm{h}$, which exceeded by far both the AOT40 threshold established by WHO (3 ppm.h for 3 months) for agricultural crops (Roy et al., 2009), and the ozone critical level for most sensitive or moderately sensitive crop plants (8.6 ppm.h for a 3-month growing season) (Mills et al., 2007). With such high ozone levels occurring recurrently year after year, Beijing area is undoubtedly an important hotspot for this pollutant, only comparable (but above) to different parts of India (Tiwari and Agrawal, 2009; Singh and Agrawal, 2011; Oksanen et al., 2013; Pandey et al., 2014; Singh et al., 2014), and with concentrations much above other parts of the world. In the short term, this situation is expected to last for years, and even to worsen as, contrary to USA and Europe, ozone precursors (mainly $\mathrm{NO}_{\mathrm{x}}$ ) are currently increasing in China at an annual rate of 5\% (Feng et al., 2015).

Current ambient ozone levels in Beijing area are known to regularly induce foliar visible injury in leaves of sensitive crops, ornamental and native vegetation (Feng et al., 2014). However, despite this recent evidence that impacts on vegetation are widespread, information on how these ozone levels affect plant physiology and ultimately biomass and yield production in this area are very scarce. The antiozonant ethylenediurea (EDU) has been used in several studies to assess the effects of ozone on plants under ambient conditions (Manning et al., 2011), avoiding the problem of 


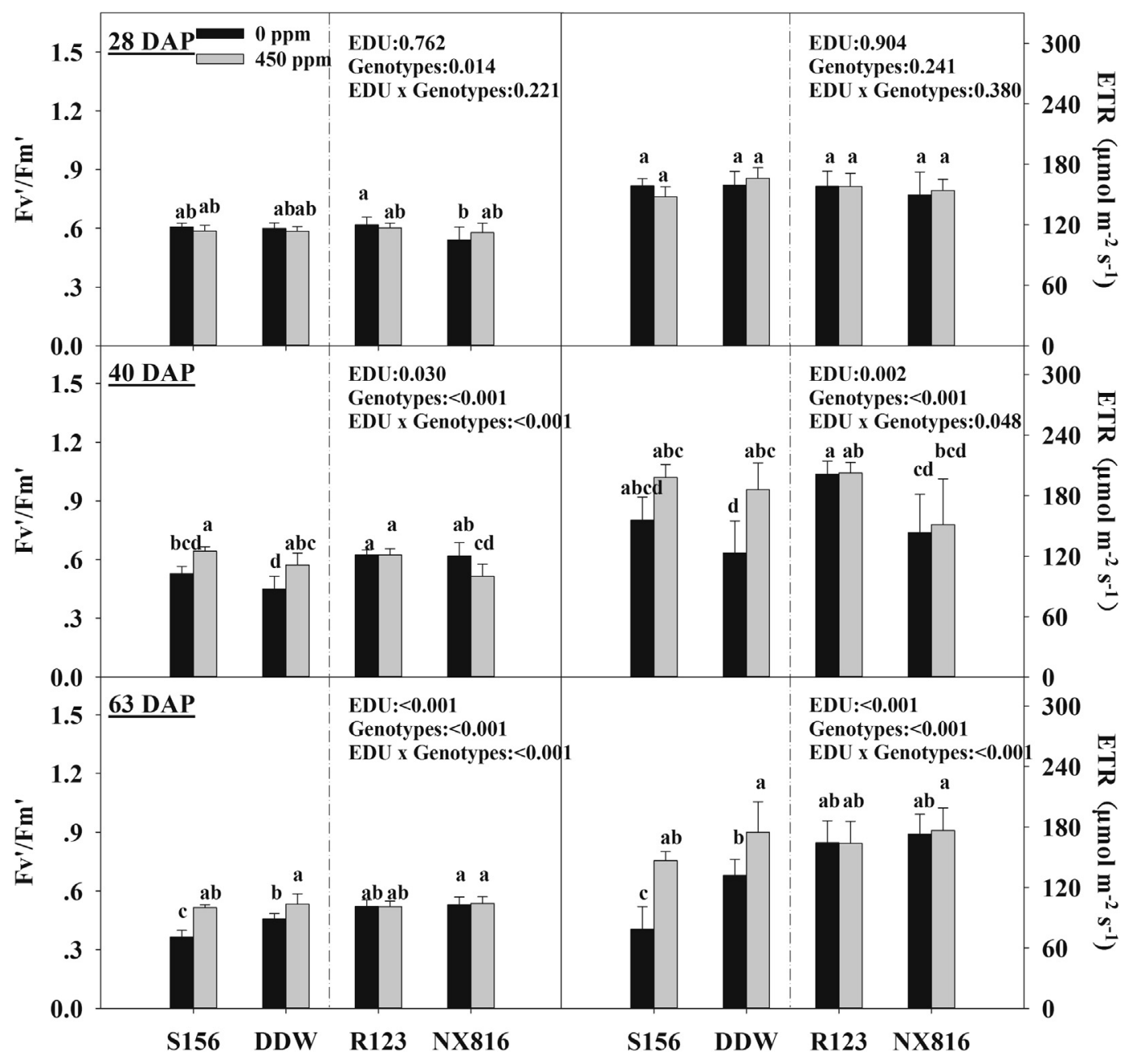

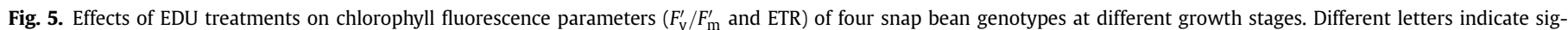
nificant differences between EDU $\times$ genotypes.

enclosure techniques such as OTCs that modify microclimatic conditions in which plants grow. In the present study, we use EDU to protect different genotypes of bean plants from ozone, therefore making it possible to assess the effects of this pollutant.

Results of this study show that there is a clear difference in ozone responses between the four genotypes. In E- treatment, genotypes S156 and DDW developed more symptoms than the two tolerant genotypes. At the middle of the growing season, sensitive genotypes, especially $\mathrm{S} 156$, showed a larger decline in $A_{\mathrm{sat}}, g_{\mathrm{s}}$, lower $V c_{\text {max }}$ and $J_{\max }$, reduced efficiency of PSII $\left(F_{\mathrm{v}}^{\prime} / F_{\mathrm{m}}^{\prime}\right.$, ETR and $\left.q \mathrm{P}\right)$. Lower chlorophyll and carotenoid contents were also observed in S156 and DDW at 40 DAP. Considering the magnitude of these responses, the varieties can be ranked in ozone sensitivity as follows: S156 $>$ DDW $>$ R123 > NX816. It is worth mentioning that S156 is used for bioindication studies due to its high ozone sensitivity, but might overestimate actual ozone impacts, while on the contrary, DDW is a commonly planted genotype around Beijing.

As the intracellular impact of ozone in leaves depends both on the uptake of this pollutant through stomata and the detoxification capacity of the cells (Matyssek et al., 2008), differences in ozone sensitivity between plants could be related to stomatal conductance (Calatayud et al., 2007; Reich, 1987) and to constitutive antioxidant levels (Dizengremel et al., 2013; Feng et al., 2010b). The differences between tolerant and sensitive genotypes reported in the present study are only partially consistent with these premises.
Based on visible injury responses, genotype NX816 was the most tolerant of all. Consistently, it showed a combination of lower $g_{s}$ during the growth phase (40 DAP) and the highest TAC, but also higher $V c_{\max }$ and $J_{\max }$ at the pod-filling stage (64 DAP), and high chlorophyll and carotenoid contents. All these features could have contributed to different extents to its higher ozone tolerance: lower $g_{s}$ is related to ozone avoidance and a higher antioxidant capacity may support the plant to cope with oxidative stress induced by ozone (Dizengremel et al., 2013). On the other hand, higher chlorophyll content, $V_{\mathrm{cmax}}$ and $J_{\max }$ values would increase photosynthesis performance and carbohydrate production. This carbon pool contributes to a higher yield but also to feed metabolic processes related to detoxification (Dizengremel et al., 2013). However, R123, also tolerant, only partially shares this combination of features, which underlines the complexity of ozone tolerance mechanisms (Overmyer et al., 2008). Regarding the yield, the differences among genotypes are not directly related to their ozone sensitivity, pointing out the fact that yield potential of each genotype depends on genetically programed features (e.g., fruiting nodes, pod numbers) besides environmental factors including ozone.

At present, the mechanisms of EDU protection from ozone are not fully understood. Our results clearly show that avoidance of ozone is not the main cause, as the addition of EDU to sensitive genotypes did not reduce (but on the contrary maintained higher) $g_{s}$ throughout the experiment in comparison with E- plants. The 


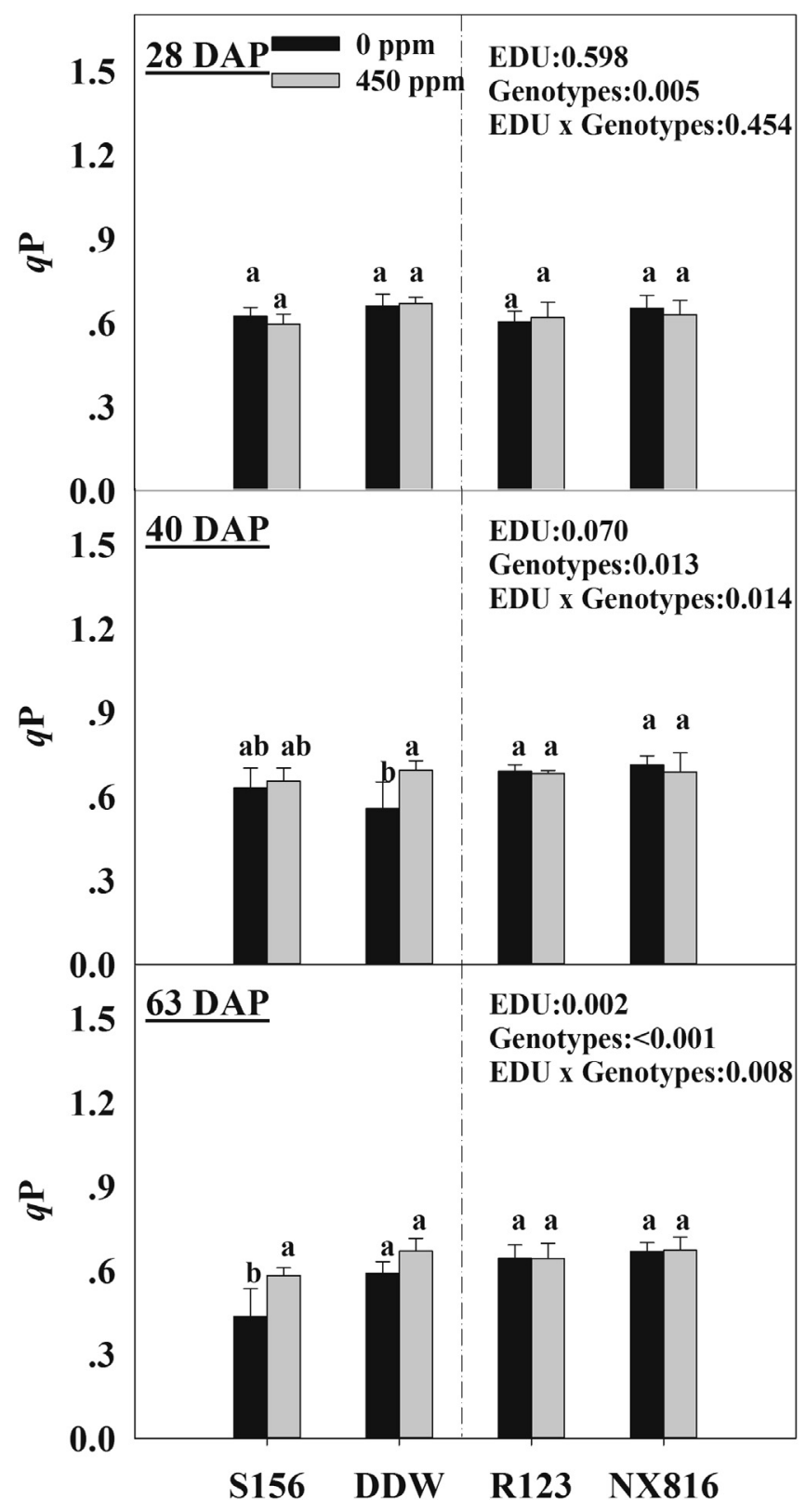

Fig. 6. Effects of EDU treatments on $q \mathrm{P}$ of four snap bean genotypes at different growth stages. Different letters indicate significant differences between EDU $\times$ genotypes.

observed reductions in $g_{\mathrm{s}}$ in E- plants could therefore be interpreted as a harmful ozone effect (e.g. Feng et al., 2008). However, contrasting results have reported: while in a meta-analysis of EDU effects on plants it was concluded that EDU did not modify the $g_{s}$ of plants (Feng et al., 2010a), individual experiments show both increasing and decreasing $g_{s}$ in EDU-treated plants and even transitory increases but final decreases (Manning et al., 2011). Protection of photosynthesis by EDU in sensitive genotypes is also a conclusion of this experiment as $A_{\mathrm{sat}}, V c_{\max }, J_{\max }$, and fluorescence parameters $\left(F_{\mathrm{v}}^{\prime} / F_{\mathrm{m}}^{\prime}\right.$, ETR and $\left.q \mathrm{P}\right)$ in the light increased. Singh and Agrawal (2011) observed that EDU increased $A$ and $F_{\mathrm{v}} / F_{\mathrm{m}}$ ratio in black gram (Vigna mugo L.) but, as far as we know, EDU effects on in vivo Rubisco carboxylation efficiency have not been previously studied. EDU treatment avoids the reduction of in vivo Rubisco carboxylation efficiency, which is regarded as one of the primary changes responsible for a decline in $\mathrm{CO}_{2}$ assimilation in ozone- exposed plants (e.g. Calatayud et al., 2010; Feng et al., 2011). The parallel reduction of fluorescence parameters $F_{\mathrm{v}}^{\prime} / F_{\mathrm{m}}^{\prime}$, ETR and $q \mathrm{P}$ under steady-state illumination in E- sensitive genotypes, may reflect a down-regulation process for adjusting the production of reductive power and chemical energy to a lower demand by the Calvin-Benson cycle (Calatayud et al., 2007). Other studies have reported that even without significant effects on photosynthesis, EDU can protect plants from ozone growth reductions (Manning et al., 2011). Notably, plants selected for the present experiment are among the most sensitive crops (Feng and Kobayashi, 2009), and they have been exposed to very high ambient ozone concentration, therefore deleterious effects of ozone on E- plants are more evident than in other studies. On the other hand, as observed in the present study in sensitive genotypes, a common response of plants to EDU is a relative increase in chlorophyll and carotenoids (Agrawal et al., 2005; Feng et al., 2010a; Singh and Agrawal, 2011). Ozone induces ROS production which damages chloroplast membranes and associated molecules such as chlorophylls. EDU prevents lipid peroxidation damages in sensitive bean genotypes, therefore maintaining higher membrane integrity (Calatayud and Barreno, 2001). Although in the present study MDA responses to EDU were not significant, there was a consistent reduction in MDA in both sensitive E+ genotypes. On the other hand, carotenoids provide photoprotection to chlorophylls and are antioxidant molecules. By maintaining their concentration higher, chlorophyll damage due to ozone is also avoided.

Manning et al. (2011) have recently reviewed the mechanisms of EDU protection to the plants. Ozone penetration into the apoplast is known to induce the formation of many secondary toxicants, some of which could be scavenged by EDU. However, direct chemical scavenging has not been demonstrated so far. EDU may also act as a plant activator as it might induce total ascorbic acid synthesis (Agrawal et al., 2005; Manning et al., 2011; Paoletti et al., 2008). AsA is a key metabolite in antioxidant system that protects plant from ROS, acting as a chemical scavenger and/or as a substrate of extracellular enzymes such as the ascorbate peroxidase (APX), therefore affecting propagation of initial ozone signal (Burkey et al., 2006; Dizengremel et al., 2013; Feng et al., 2010b). Differences in AsA content have been related to differences in ozone sensitivity (Burkey et al., 2003; Feng et al., 2010b). In our study, higher total AsA in NX816 could partly explain the higher ozone tolerance of this genotype, but no significant responses to EDU were observed. At present, contrasting responses of AsA to EDU have been reported, as well as inconsistent responses of the AsA pool to ozone (Manning et al., 2011). Further studies integrating the AsA system into the overall regenerating machinery and considering apoplast and symplast components separately are needed in order to better understand AsA responses to ozone and to EDU, as well as their interactions. Phenolic metabolites are suggested to play a protective role against oxidative stress as antioxidants (Kangasjärvi et al., 1994). In an EDU-treated soybean genotype, total phenolics content decreased (Rai et al., 2015); it was interpreted that a relative abundance of carbon in EDU-treated plants influenced the rate at which the substrate, i.e. phenylalanine is diverted to protein synthesis, as protein and phenolic allocation are inversely correlated (Jones and Hartley, 1999). In the present experiment, however, differences in phenolics between genotypes were not consistently related to ozone sensitivity of the genotypes and EDU had no significant effect; indeed mean phenolic values were higher in $\mathrm{E}+$ plants. TAC in E+ plants was much higher than in E- plants $(P=0.057)$, suggesting that EDU contributes to keep total antioxidant levels higher. TAC represents the cumulative capacity of leaf tissue to scavenge free radicals.

Across all genotypes, EDU significantly increased both shoot and root biomass, but only significant increase in the shoot biomass of 


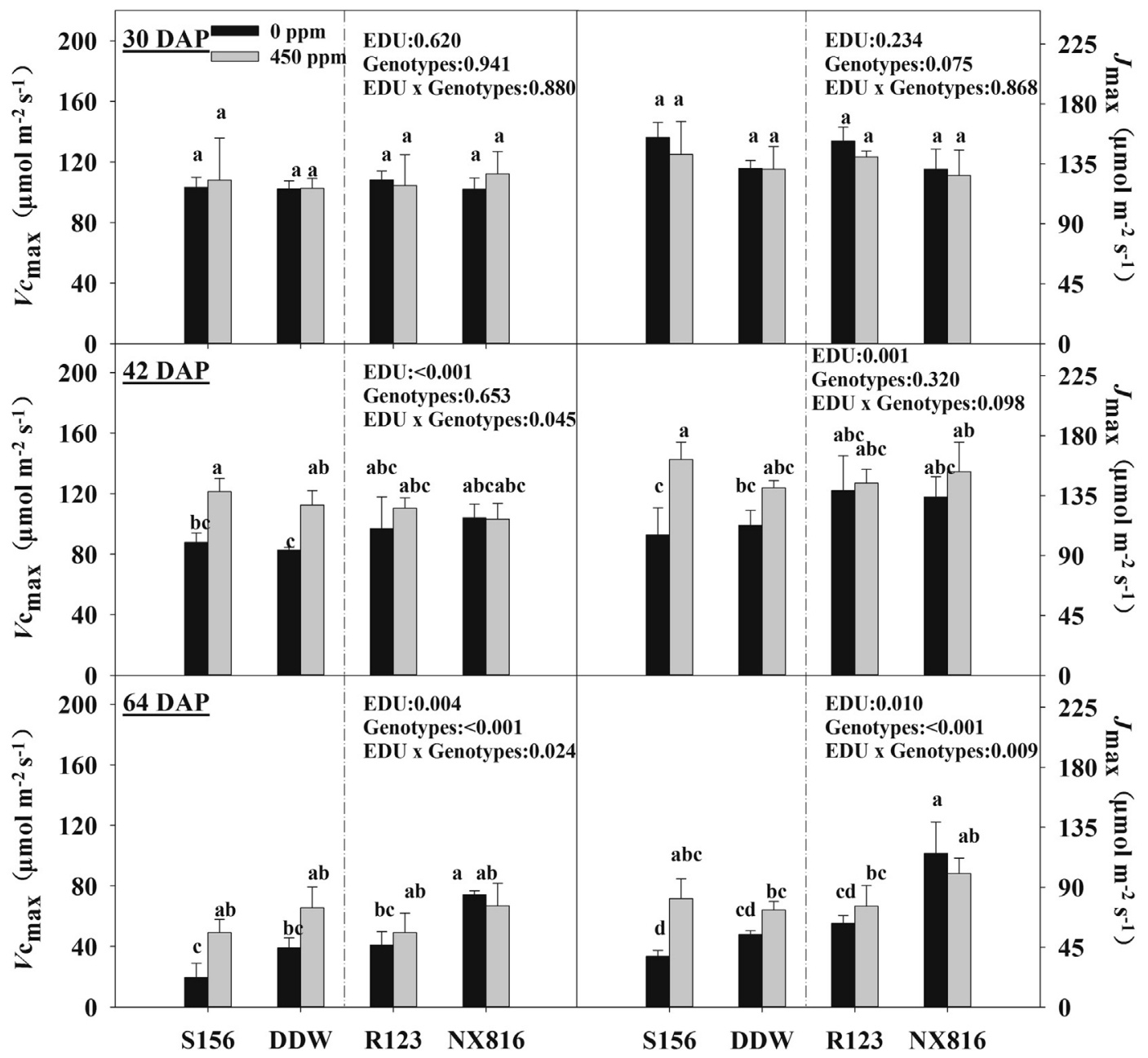

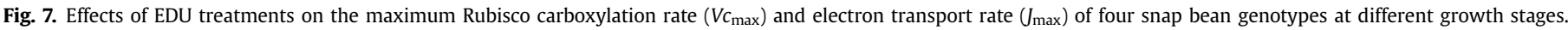
Different letters indicate significant differences between EDU $\times$ genotypes.

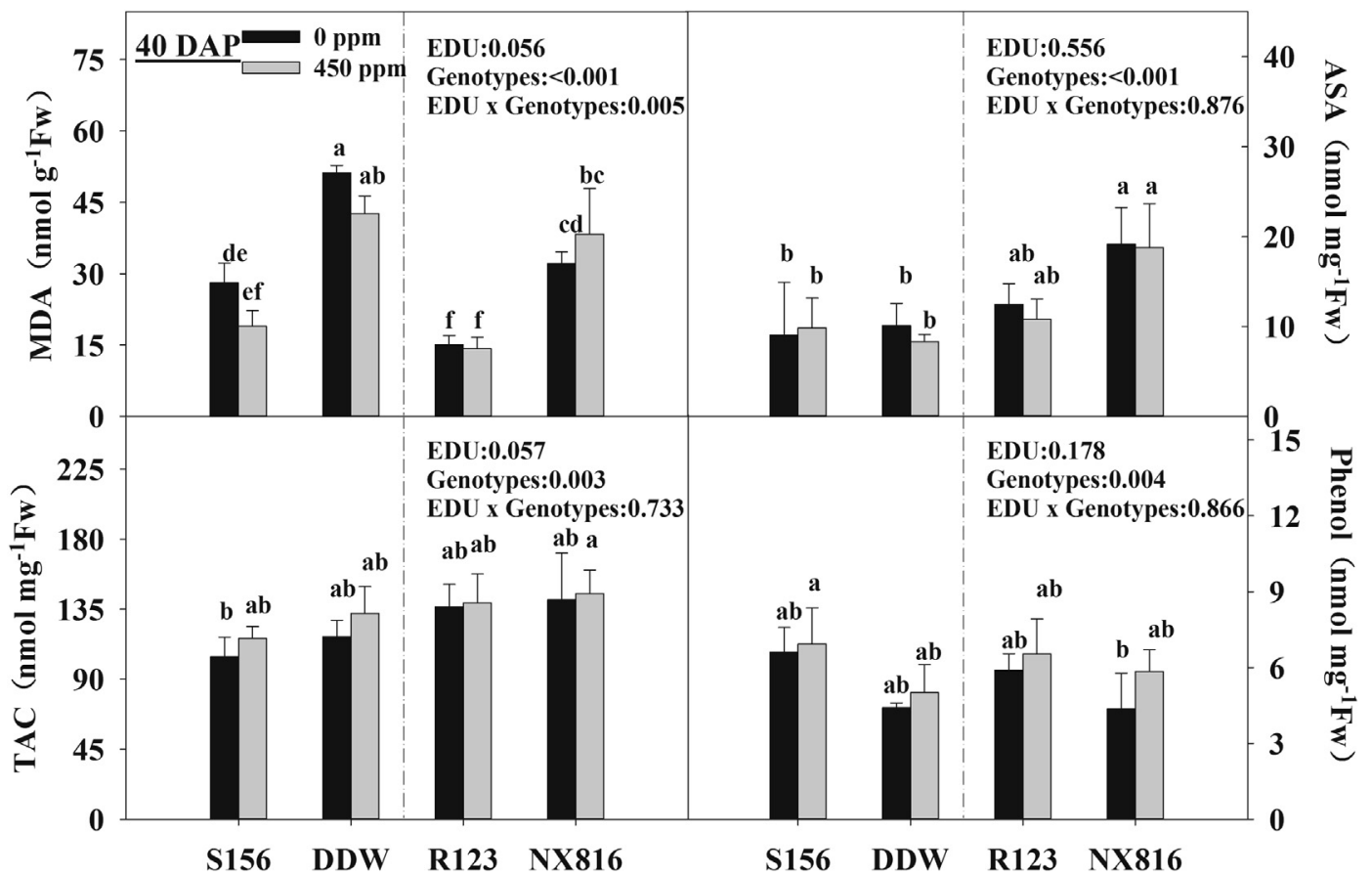

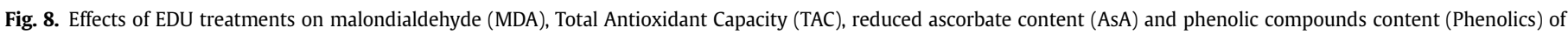
four snap beans during the flowering phase. Different letters indicate significant differences between EDU $\times$ genotypes. 


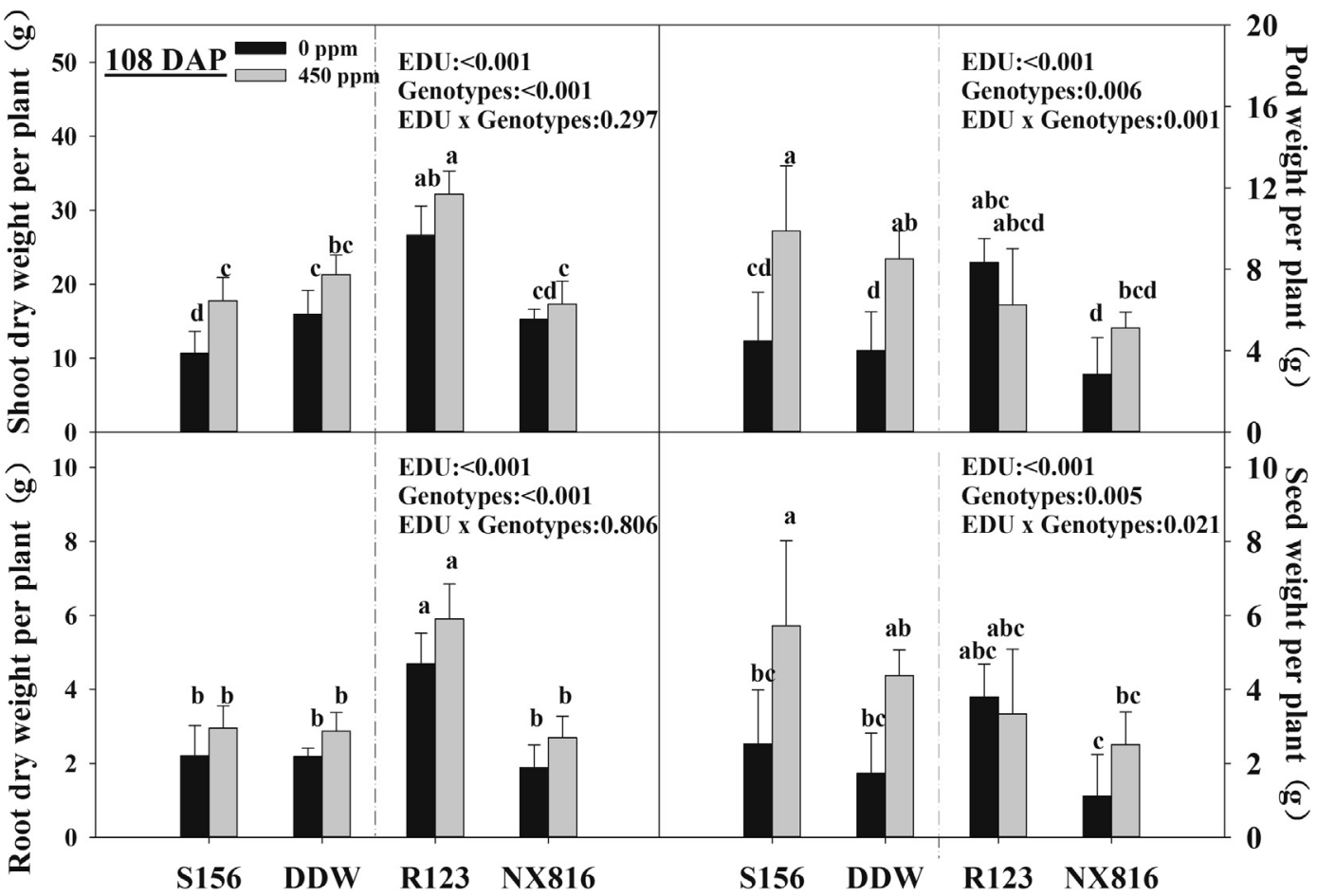

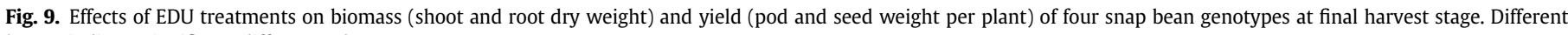
letters indicate significant differences between EDU $\times$ genotypes.

S156. Biomass increases by EDU have been observed previously in snap bean (Brunschon-Harti et al., 1995), as well as in other crops (Feng et al., 2010a). Increases in pod and seed yield in E+ plants were about 50\% in sensitive genotypes S156 and DDW, but not significant in tolerant ones. In a meta-analysis of EDU effects by Feng et al. (2010a), EDU treatment significantly increased yield in beans by about $10 \%$ and seed weight by $3.8 \%$. Therefore, yield increases in E+ sensitive genotypes of the present study are comparatively high. Under the high ozone levels experienced in Beijing area, EDU has proven to effectively protect sensitive genotypes increasing yield through a higher photosynthetic performance, and by reducing leaf injury, therefore preserving the integrity of photosynthetic tissues and ultimately increasing the available carbon for yield. In another study under lower ozone levels, plant development and yield production in different bean varieties (including S156 and R123) showed more complex responses that were related to developmental stages, duration of EDU applications, and fluctuations in ambient ozone (Elagoz and Manning, 2005).

\section{Conclusions}

In summary, under conditions with high ozone levels as those prevailing in Beijing area, EDU conferred an important protection to sensitive bean genotypes, increasing photosynthesis performance, maintaining a higher antioxidant capacity, and finally leading to higher biomass and/or pod yields, but did not affect tolerant genotypes. In this part of China, yield losses in very sensitive bean genotypes such as DDW may be around 50\%, underlining the importance of genotype selection and the need of effective policies for ozone reduction. The ozone problem in China has been partly covered by other urgent air quality issues such as the high levels of particulate matter, but current levels represent a serious threat both for human health and for food security. Measures to reduce ozone pollution in China are urgently needed, even more when they are a matter of transnational concern due to long range transport (Hand, 2014).

\section{Acknowledgements}

This study has been funded by the Hundred Talents Program, Chinese Academy of Sciences. Collaboration between RCEES and Fundación CEAM has been possible thanks to project AMIS (Fate and Impact of Atmospheric Pollutants, PIRSES-GA-2011-295132), and by the Chinese Academy of Sciences Visiting Professorships for Senior International Scientists (Grant Number: 2013T2Z0009). Fundación CEAM also acknowledges the support of project DESESTRES (PROMETEOII/2014/038) and Generalitat Valenciana.

\section{Appendix A. Supplementary data}

Supplementary data related to this article can be found at http:// dx.doi.org/10.1016/j.envpol.2015.05.043.

\section{References}

Agrawal, S.B., Singh, A., Rathore, D., 2005. Role of ethylene diurea (EDU) in assessing impact of ozone on Vigna radiata L. plants in a suburban area of Allahabad (India). Chemosphere 61, 218-222.

Ainsworth, E.A., Gillespie, K.M., 2007. Estimation of total phenolic content and other oxidation substrates in plant tissues using Folin-Ciocalteu reagent. Nat. Protoc. 2, 875-877.

Benzie, I.F.F. Strain, JJ. 1996. The ferric reducing ability of plasma (FRAP) as a measure of 'Antioxidant power': the FRAP assay. Anal. Biochem. 239, 70-76.

Blum, O., Bytnerowicz, A., Manning, W., Popovicheva, L., 1998. Ambient tropospheric ozone in the Ukranian Carpathian Mountains and Kiev region: detection with passive samplers and bioindicator plants. Environ. Pollut. 98, 299-304.

Brunschon-Harti, S., Fangmeier, A., Jager, H.J., 1995. Effects of ethylenediurea and ozone on the antioxidant systems in beans (Phaseolus vulgaris). Environ. Pollut. 9, 94-104.

Burkey, K.O., Eason, G., Fiscus, E.L., 2003. Factors that effect leaf extracellular ascorbic acid content and redox status. Physiol. Plant. 117, 51-57. 
Burkey, K.O., Miller, J.E., Fiscus, E.L., 2005. Assessment of ambient ozone effects on vegetation using snap bean as a bioindicator species. J. Environ. Qual. 34, 1081-1086.

Burkey, K.O., Miller, J.E., Fiscus, E.L., 2012. Field assessment of a snap bean ozone bioindicator system under elevated ozone and carbon dioxide in a free air system. Environ. Pollut. 166, 167-171.

Burkey, K.O., Neufeld, H.S., Souza, L., Chappelka, A.H., Davison, A.W., 2006. Seasonal profiles of leaf ascorbic acid content and redox state in ozone-sensitive wildflowers. Environ. Pollut. 143, 427-434.

Calatayud, A., Barreno, E., 2001. Chlorophyll fluorescence, antioxidant enzymes and lipid peroxidation in tomato in response to ozone and benomyl. Environ. Pollut. $115,283-289$.

Calatayud, V., Cerveró, J., Sanz, M.J., 2007. Foliar, physiologial and growth responses of four maple species exposed to ozone. Water Air. Soil Pollut. 185, 239-254.

Calatayud, V., Marco, F., Cerveró, J., Sanchez-Peña, G., Sanz, M.J., 2010. Contrasting ozone sensitivity in related evergreen and deciduous shrubs. Environ. Pollut. $158,3580-3587$.

Dentener, F., Stevenson, D., Cofala, J., Mechler, R., Amann, M., Bergamaschi, P., Raes, F., Derwent, R., 2005. The impact of air pollutant and methane emission controls on tropospheric ozone and radiative forcing: CTM calculations for the period 1990-2030. Atmos. Chem. Phys. 5, 1731-1755.

Dizengremel, P., Jolivet, Y., Tuzet, A., Rainieri, A., Le Thiec, D., 2013. Integrative leaflevel ozone phytotoxic ozone dose assessment for forest risk modelling. In: climate change, air pollution and global challenges. Dev. Environ. Sci. 13, 267-288.

Elagoz, V., Manning, W.J., 2005. Responses of sensitive and tolerant bush beans (Phaseolus vulgaris L.) to ozone in open-top chambers are influenced by phenotypic differences, morphological characteristics, and the chamber environment. Environ. Pollut. 136, 371-383.

Feng, Z., Hu, E., Wang, X., Jiang, L., Liu, X., 2015. Ground-level $\mathrm{O}_{3}$ pollution and its impacts on food crops in China: a review. Environ. Pollut. 199, 42-48.

Feng, Z., Kobayashi, K., 2009. Assessing the impacts of current and future concentrations of surface ozone on crop yield with meta-analysis. Atmos. Environ. 43, 1510-1519.

Feng, Z., Kobayashi, K., Ainsworth, E.A., 2008. Impact of elevated ozone concentration on growth, physiology, and yield of wheat (Triticum aestivum L.): a metaanalysis. Glob. Change Biol. 14, 2696-2708.

Feng, Z., Sun, J., Wan, W., Hu, E., Calatayud, V., 2014. Evidence of widespread ozoneinduced visible injury on plants in Beijing, China. Environ. Pollut. 193, 296-301.

Feng, Z., Wang, S., Szantoi, Z., Chen, S., Wang, X., 2010a. Protection of plants from ambient ozone by applications of ethylenediurea (EDU): a meta-analytic review. Environ. Pollut. 158, 3236-3242.

Feng, Z., Pang, J., Kobayashi, K., Zhu, J.G., Ort, D.R., 2011. Differential responses in two varieties of winter wheat to elevated ozone concentration under fully open-air field conditions. Glob. Change Biol. 17, 580-591.

Feng, Z., Pang, J., Nouchi, I., Kobayashi, K., Yamakawa, T., Zhu, J.G., 2010b. Apoplastic ascorbate contributes to the differential ozone sensitivity in two varieties of winter wheat under fully open-air field conditions. Environ. Pollut. 158, 3539-3545

Fiscus, E.L., Booker, F.L., Burkey, K.O., 2005. Crop responses to ozone: uptake, modes of action, carbon assimilation and partitioning. Plant Cell. Environ. 28, 997-1011.

Fiscus, E.L., Booker, F.L., Sadok, W., Burkey, K.O., 2012. Influence of atmospheric vapour pressure deficit on ozone responses of snap bean (Phaseolus vulgaris L.) genotypes. J. Exp. Bot. 63, 2557-2564.

Flowers, M.D., Fiscus, E.L., Burkey, K.O., Booker, F.L., Dubois, J.J.B., 2007. Photosynthesis, chlorophyll fluorescence, and yield of snap bean (Phaseolus vulgaris L.) genotypes differing in sensitivity to ozone. Environ. Exp. Bot. 61, 190-198.

Furlan, C.M., Moreas, R.M., Bulboves, P., Domingos, M., Salatino, A., Sanz, M.J., 2007. Psidium guajava 'Paluma' (the guava plant) as a new bio-indicator of ozone in the tropics. Environ. Pollut. 147, 691-695.

Gatta, L., Mancino, L., Federico, R., 1997. Translocation and persistence of EDU (ethylenediurea) in plants: the relationship with its role in ozone damage. Environ. Pollut. 96, 445-448.

Gillespie, K.M., Ainsworth, E.A., 2007. Measurement of reduced, oxidized and total ascorbate content in plants. Nat. Protoc. 2, 871-874.

Hand, E., 2014. China blamed for U.S. ozone. Science 6202, 1233.

Harmens, H., Mills, G., Hayes, F., Jones, L., Norris, D., Cooper, D., et al., 2009. Programme Coordination Centre for the ICP Vegetation. ICP Vegetation Annual Report 2008/2009. Centre for Ecology and Hydrology, Bangor, UK. Available online at: http://icpvegetation.ceh.ac.uk/publications/documents/ICPVegetati onannualreport2008-09.pdf.

Hassan, I.A., Ashmore, M.R., Bell, J.N.B., 1995. Effect of ozone on radish and turnip under Egyptian field conditions. Environ. Pollut. 89, 107-114.

Heath, R.L., Parker, L., 1968. Photoperoxidation in isolated chloroplasts. I. Kineticsand stoichiometry of fatty acid peroxidation. Arch. Biochem. Biophysics 125, 189-198.

Intergovernmental Panel on Climate Change (IPCC), 2013. Fifth Assessment Report. http://www.ipcc.ch/report/ar5/index.shtml.

Jiang, F., Zhou, B., Liu, O, Wang, T., Zhuang, B., Wang, X., 2012. Modeling tropospheric ozone formation over East China in springtime. J. Atmos. Chem. 66, 303-319.

Jones, C.G., Hartley, S.E., 1999. A protein competition model of phenolic allocation. Oikos 86, 27-44.

Kangasjärvi, J., Talvinen, J., Utriainen, M., Karjalainen, R., 1994. Plant defence systems induced by ozone. Plant Cell Environ. 17, 783-794.

Lichtenthaler, H.K., 1989. Chlorophylls and carotenoids: pigments of photosynthetic biomembranes. Methods Enzym. 148, 350-382.

Manning, W.J., Paoletti, E., Sandermann Jr., H., Ernst, D., 2011. Ethylenediurea (EDU) a research tool for assessment and verification of the effects of ground leve ozone on plants under natural conditions. Environ. Pollut. 159, 3283-3293.

Matyssek, R., Sandermann, H., Wieser, G., Booker, F., Cieslik, S., Musselman, R. Ernst, D., 2008. The challenge of making ozone risk assessment for forest trees more mechanistic. Environ. Pollut. 156, 567-582.

Mills, G., Buse, A., Gimeno, B., Bermejo, V., Holland, M., Emberson, L., Pleijel, H., 2007. A synthesis of AOT40-based response functions and critical levels of ozone for agricultural and horticultural crops. Atmos. Environ. 41, 2630-2643.

Oksanen, E., Pandey, V., Pandey, A.K., Keski-Saari, S., Kontunen-Soppela, S. Sharma, C., 2013. Impacts of increasing ozone on Indian plants. Environ. Pollut. $177,189-200$.

Overmyer, $\mathrm{K}$., Kollist, $\mathrm{H}$., Tuominen, $\mathrm{H}$., Betz, C. Langebartels, C., Wingsle, G., Kangasjärvi, S., Brader, G., Mullineaux, P., Kangasjärvi, J., 2008. Complex phenotypic profiles leading to ozone sensitivity in Arabidopsis thaliana mutants. Plant Cell Environ. 31, 1237-1249.

Pandey, A.K., Majumder, B., Keski-Saari, S., Kontunen-Soppela, S., Pandey, V. Oksanen, E., 2014. Differences in responses of two mustard genotypes to ethylenediurea (EDU) at high ambient ozone concentrations in India. Agri. Ecosyst. Environ. 196, 158-166.

Paoletti, E., Contran, N., Manning, W.J., Castagna, A., Ranieri, A., Tagliaferro, F., 2008. Protection of ash (Fraxinus excelsior) trees from ozone injury by ethylenediurea (EDU): roles of biochemical changes and decreased stomatal conductance in enhancement of growth. Environ. Pollut. 155, 464-472.

Rai, R., Agrawal, M., Kumar, K., Agrawal, S.B., Emberson, L., Büker, P., 2015. Application of ethylene diurea (EDU) in assessing the response of a tropical soybean cultivar to ambient $\mathrm{O}_{3}$ : nitrogen metabolism, antioxidants, reproductive development and yield. Ecotoxicol. Environ. Saf. 112, 29-38.

Reich, P.B., 1987. Quantifying plant response to ozone: a unifying theory. Tree Physiol. 3, 63-91.

Roy, S.D., Beig, G., Ghude, S.D., 2009. Exposure-plant response of ambient ozone over the tropical Indian region. Atmos. Chem. Phys. 9, 5253-5260.

Sharkey, T., Bernacchi, C.J., Farquhar, G.D., Singsaas, E.L., 2007. Fitting photosynthetic carbon dioxide response curves for $C_{3}$ leaves. Plant Cell Environ. 30, 1035-1040.

Singh, S., Agrawal, S.B., 2011. Ambient ozone and two black gram cultivars: an assessment of amelioration by the use of ethylenediurea. Acta Physiol. Plant. 33, 2399-2411.

Singh, S., Agrawal, S.B., Agrawal, M., 2009. Differential protection of ethylenediurea (EDU) against ambient ozone for five cultivars of tropical wheat. Environ. Pollut. 157, 2359-2367.

Singh, A.A., Agrawal, S.B., Shahi, J.P., Agrawal, M., 2014. Investigating the response of tropical maize (Zea mays L.) cultivars against elevated levels of $\mathrm{O}_{3}$ at two developmental stages. Ecotoxicology 23, 1447-1463.

Tiwari, S., Agrawal, M., 2009. Protection of palak (Beta vulgaris L.var Allgreen) plants from ozone injury by ethylenediurea (EDU): roles of biochemical and physiological variations in alleviating the adverse impacts. Chemosphere 75 $1492-1499$.

Tiwari, T., Agrawal, M., 2010. Effectiveness of different EDU concentrations in ameliorating ozone stress in carrot plants. Ecotoxicol. Environ. Saf. 73, 1018-1027.

Van Dingenen, R., Dentener, F.J., Raes, F., Korl, M.C., Emberson, L., Cofala, J., 2009. The global impact of ozone on agricultural crop yields under current and future air quality legislation. Atmos. Environ. 43, 604-618.

Vingarzan, R., 2004. A review of surface ozone background levels and trends. Atmos, Environ. 38, 3431-3442.

Wang, H.X., Zhou, L.J., Tang, X.Y., 2006. Ozone concentrations in rural regions of the Yangtze Delta in China. J. Atmos. Chem. 54, 255-265.

Wang, X.K., Zheng, Q.W., Yao, F.F., Chen, Z., Feng, Z.Z., Manning, W.J., 2007. Assessing the impact of ambient ozone on growth and yield of a rice (Oryza sativa L.) and a wheat (Triticum aestivum L.) cultivar grown in the Yangtze Delta, China, using three rates of application of ethylenediurea (EDU). Environ. Pollut. 148 $390-395$

Wang, X.P., Mauzerall, D.L., 2004. Characterizing distributions of surface ozone and its impact on grain production in China, Japan and South Korea: 1990 and 2020. Atmos. Environ. 38, 4383-4402.

Zhang, W., Wang, G., Liu, X., Feng, Z., 2014. Effects of elevated $\mathrm{O}_{3}$ exposure on seed yield, $\mathrm{N}$ concentration and photosynthesis of nine soybean cultivars (Glycine max (L.) Merr.) in Northeast China. Environ. Pollut. 226, 172-181. 